University of Nebraska - Lincoln

DigitalCommons@University of Nebraska - Lincoln

\title{
Late Holocene island reef development on the inner zone of the northern Great Barrier Reef: Insights from Low Isles Reef
}

Tracy D. Frank

University of Nebraska-Lincoln, tfrank2@unl.edu

Follow this and additional works at: https://digitalcommons.unl.edu/geosciencefacpub

Part of the Earth Sciences Commons

Frank, Tracy D., "Late Holocene island reef development on the inner zone of the northern Great Barrier Reef: Insights from Low Isles Reef" (2008). Papers in the Earth and Atmospheric Sciences. 111.

https://digitalcommons.unl.edu/geosciencefacpub/111

This Article is brought to you for free and open access by the Earth and Atmospheric Sciences, Department of at DigitalCommons@University of Nebraska - Lincoln. It has been accepted for inclusion in Papers in the Earth and Atmospheric Sciences by an authorized administrator of DigitalCommons@University of Nebraska - Lincoln. 
Published in Australian Journal of Earth Sciences 55 (2008), pp. 669-683; doi: 10.1080/08। 2009080I982835

Copyright (c) 2008 Geological Society of Australia; published by Taylor \& Francis. Used by permission.

Submitted June 28, 2007; accepted January 10, 2008.

\title{
Late Holocene island reef development on the inner zone of the northern Great Barrier Reef: Insights from Low Isles Reef
}

\author{
Tracy D. Frank \\ Department of Geosciences, University of Nebraska-Lincoln, Lincoln, NE 68588-0340, USA; tfrank2@unl.edu
}

\begin{abstract}
A sedimentological and stratigraphic study of Low Isles Reef off northern Queensland, Australia was carried out to improve understanding of factors that have governed Late Holocene carbonate deposition and reef development on the inner to middle shelf of the northern Great Barrier Reef. Low Isles Reef is one of 46 low wooded island-reefs unique to the northern Great Barrier Reef, which are situated in areas that lie in reach of river flood plumes and where inter-reef sediments are dominated by terrigenous mud. Radiocarbon ages from surface and subsurface sediment samples indicate that Low Isles Reef began to form at ca 3000 y BP, several thousand years after the Holocene sea-level stillstand, and reached sea-level soon after (within $\sim 500$ years). Maximum reef productivity, marked by the development of mature reef flats that contributed sediment to a central lagoon, was restricted to a narrow window of time, between 3000 and 2000 y BP.This interval corresponds to: (i) a fall in relative sea-level, from I m above present at ca 5500 y BP to the current datum between 3000 and 2000 y BP; and (ii) a regional climate transition from pluvial (wetter) to the more arid conditions of today. The most recent stage of development (ca 2000-0 y BP) is characterized by extremely low rates of carbonate production and a dominance of destructive reef processes, namely storm-driven remobilization of reef-top sediments and transport of broken coral debris from the reef front and margins to the reef top. Results of the present study enhance existing models of reef development for the Great Barrier Reef that are based on regional variations in reef-surface morphology and highlight the role of climate in controlling the timing and regional distribution of carbonate production in this classic mixed carbonate-siliciclastic environment.
\end{abstract}

Keywords: Australia, carbonate sediments, Great Barrier Reef, Holocene, Queensland

\section{Introduction}

Genetic classifications of the thousands of individual carbonate buildups that together comprise the Great Barrier Reef of Australia have been proposed by numerous authors (Spender 1930; Fairbridge 1950, 1967; Maxwell 1968; Flood 1977a; Flood \& Orme 1977; Jell \& Flood 1978). These classifications place reefs into three categories, which occur in zones oriented parallel to the shelf and correspond to increases in water depth with distance from the coast (Hopley 1982): fringing, platform, and ribbon reefs. Fringing reefs occur adjacent to the shoreline and around shelf islands; the former are restricted mainly to the northern Great Barrier Reef (north of Cairns). The inner and middle parts of the shelf are characterized by a shelf-parallel belt of platform reefs, which may be planar or may contain a central depression or lagoon. The outer shelf is characterized by ribbon reefs, linear buildups that are exposed to open ocean seas and in which growth is directed primarily upward. Ribbon reefs are typically oriented with their long axes parallel to the shelf edge (per- pendicular to incoming waves and swell) and do not develop true lagoons.

The different reef types have been suggested to reflect particular stages of reef development (Maxwell 1968; Flood 1977a; Hopley 1982). Juvenile reefs are dominated by vertical growth, which enhances the original topographic relief, whereas the reefs considered more mature have reached sea-level and show evidence of lateral growth. In the latter case, reef flats are developed around the periphery of a central lagoon, which is gradually infilled by the lateral transport of sediment. According to this model, reefs which nucleated on the highest platforms and/or in the shallowest waters (mid to inner shelf) have reached modern sea-level (and maturity) sooner, whereas those that nucleated on deeper platforms (outer shelf) are still struggling to reach sea-level and are thus at a more juvenile stage of development.

Planar platform reefs are generally smaller in size and display complex morphologies relative to the platform reefs with central lagoons that tend to occupy deeper areas of the middle to outer shelf. The former are considered to rep- 
resent the final stage of reef development (Maxwell 1968; Flood 1977a; Hopley 1982). These so-called "senile" reefs (Hopley 1982) are characterized a flat-topped profile and typically possess islands composed of either reef-derived carbonate debris or, in a few cases, mainland bedrock.

The purpose of the present study is to examine the Holocene development of Low Isles Reef, a classic senile reef of the type that is abundant in the northern region (between 10 and $16^{\circ} \mathrm{S}$ ) of the Great Barrier Reef (Maxwell 1968). Information regarding recent (past $\sim 100$ years) reef development obtained from historical data and reef-top surveys (Frank \& Jell 2006) is integrated with sedimentological, stratigraphic and radiocarbon analyses of a suite of surfacesediment samples and vibrocores from Low Isles Reef. Results provide insight into rates and types of processes that have controlled the development of terrigenous-influenced reefs that form part of the larger Great Barrier Reef Province and provide a test for genetic models of reef development that are based on variations in the geomorphology of reefs across the Queensland shelf.

\section{Regional Setting}

The Great Barrier Reef carbonate province comprises 42500 carbonate buildups in a zone that extends $>2300$ $\mathrm{km}$ along the Queensland coast from $9^{\circ} 15^{\prime} \mathrm{S}$ to Lady Elliot Reef, located at $24^{\circ} 07^{\prime} \mathrm{S}$ (Bennett 1971; Hopley 1982). Low Isles Reef, situated in the southern reaches of the northern region of the Great Barrier Reef Province (Figure 1), lies $\sim 15 \mathrm{~km}$ offshore and rises from $\sim 20 \mathrm{~m}$ water depth. Seismic profiling and limited vibrocoring in nearby areas (Orme $e t$ al. 1978a, b; Searle et al. 1980) has shown that Low Isles sits near the outer edge of a shore-connected, seaward-thinning wedge of post-glacial terrigenous sediment that defines the inner shelf (Maxwell 1968; Belperio 1983; Johnson et al. 1986). These muddy sediments are frequently remobilized by waves and longshore currents, resulting in turbid conditions in nearshore areas, including in the vicinity of Low Isles Reef (Larcombe \& Woolfe 1999). These conditions contrast with those of the main areas of platform reef development on the middle and outer shelf, where surface

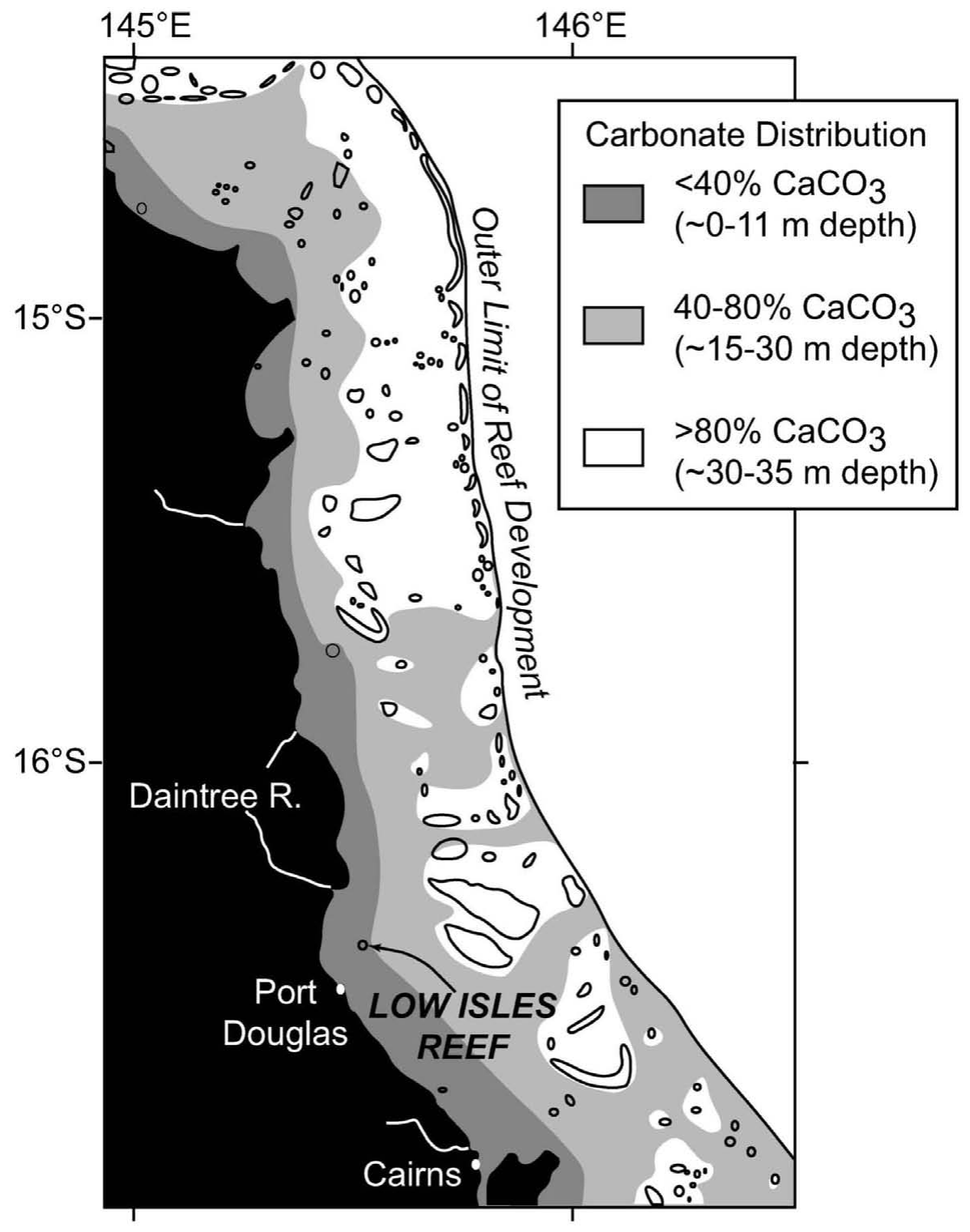

Figure I. Map showing the location of Low Isles Reef in the northern province of the Great Barrier Reef and the distribution of terrigenous sediment across the Queensland shelf (after Maxwell 1968). 
sediments are dominated by locally derived skeletal sands, and turbidity is low (Maxwell 1968; Flood et al. 1978).

The Great Barrier Reef is affected by a semi-diurnal tidal regime characterized by an unusually high tidal range relative to most modern coral reef provinces (Maxwell 1968; Hopley 1982). The largest tidal variations at Low Isles Reef, 3-3.5 m, occur during the summer and winter solstices. The Southeast Trade Winds dominate, with the effects of the Northwest Monsoon apparent only sporadically during the southern hemisphere summer (December-February). Low Isles Reef lies within the sector most often affected by tropical cyclones, which generally follow a parabolic, anticlockwise course from the Coral Sea to the northwest (Maxwell 1968). Although the ribbon reef barrier along the shelf edge provides some protection, cyclonic storms have the capacity to create storm surges on the middle and inner shelf that exceed $1 \mathrm{~m}$ for cyclones with a 10-year return period, upon which waves reaching 5-7 $\mathrm{m}$ in height can be superimposed (Hopley 1982 and references therein), as modeled by Hardy et al. (2003).

Planar platform reefs such as Low Isles, described as "senile" by Hopley (1982), are characterized by their flattopped morphology, a consequence of the fact that coral growth has reached sea-level, and accommodation space has been filled. The geomorphological features common to Low Isles and similar reefs of the wet tropics include a vegetated sand cay developed via eolian deposition on the leeward end of a bare, sandy reef flat, elongate deposits of coral shingle (cobble-boulder-sized coral debris) along the windward margin, and often a mangrove swamp (Figure 2). Carbonate production is limited to the reef margin and shallow subtidal ponds developed in topographic lows on the reef flat that retain $<50 \mathrm{~cm}$ of water at low spring tide (Frank \& Jell 2006). The main producers of carbonate sediment are Halimeda, prevalent on the reef margin, and benthic foraminifera that live attached to plants that inhabit subtidal ponds (e.g. non-calcareous macroalgae and seagrass) and the reef crest (e.g. Halimeda and Chlorodesmis). Because of the limited accommodation space on the reef top, carbonate production by calcareous red algae and scleractinian corals is confined almost exclusively to the reef crest and forereef.

Through comparison of the modern surface of Low Isles Reef with a suite of aerial photographs, maps and reports dating from 1928 to the present, Frank \& Jell (2006) demonstrated that the current distribution of geomorphic elements on the Low Isles reef top is largely a reflection of the effects of historical cyclones, with day-to-day processes and possible changes in sea-level (Gornitz 1993; Mitchell 1999) playing relatively minor roles. Over the past century, highenergy conditions associated with historical cyclones and other heavy-weather events have generated and remobilized coarse sediment, forming elongate, asymmetric ridges or ramparts of coral shingle along the windward periphery. As sea-level rose over the past century, these ramparts have gradually retreated toward the reef interior, filling in and ultimately destroying an extensive system of subtidal ponds or moats in which scleractinian corals flourished as recently as 1928. Storm processes have also triggered lessabrupt transformations. For example, the gradual development of a composite coral shingle rampart along the windward periphery of the reef has provided an effective barrier for the mangrove swamp interior against waves and swells, allowing the swamp to expand $150 \%$ since 1928.
Figure 2. Queensland Beach Protection Authority aerial photograph of Low Isles Reef, taken in 2001, showing the major features of low wooded island-reefs, including a sandy reef flat (RF) with a vegetated sand cay on the leeward end (SC), a mangrove swamp (MS) and shingle ramparts (SR), elongate deposits of coral rubble along the windward reef margin.

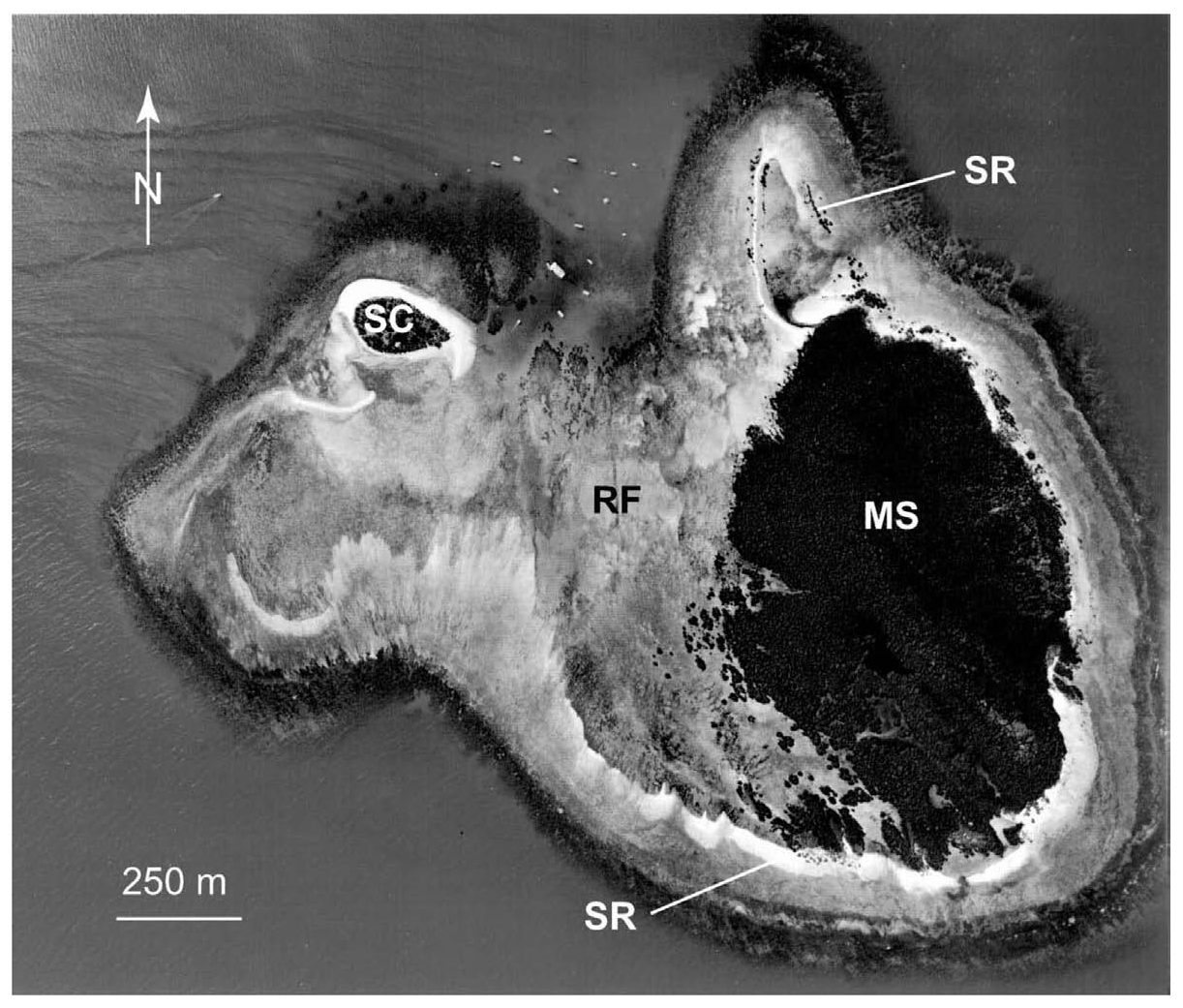




\section{Methods}

\section{Sample collection}

Locations of sediment and core samples are indicated on Figure 3. Sediment samples from the reef top were collected on foot during low spring tides. Additional samples, from subtidal areas to the north of Low Isles Reef, were collected using a clamshell sampler deployed from a boat. A series of cores were collected in areas of the reef top where the absence of lithified material allowed penetration via vibrocoring. The cores were captured inside aluminum pipes (70 mm irrigation pipes), which were power-assisted into the subsurface by a vibrocore device comprising a vibrating steel head clamped to the pipe and attached by hydraulic hose to a portable generator unit. Sampling locations were recorded using a hand-held GPS unit. The accuracy of GPS data to $< \pm 2 \mathrm{~m}$ was verified using a permanent survey marker affixed to a lighthouse located on the sand cay.

\section{Petrographic methods}

Sediment samples were subjected to standard granulometric analysis as outlined by Folk (1974) to determine variations in mean grainsize $\left(M_{z}\right)$ and inclusive graphic standard deviation $\left(\sigma_{1}\right)$ in samples dominated by mud and sand (Table 1). $M_{\mathrm{z}}$ and $\sigma_{1}$ were not determined on samples in which $>50 \%$ of the cumulative weight percentage was contained in the gravel size class. The proportions of different allochem types in the sand and gravel size fractions $(-2$ to $+0.5 \varphi)$ were determined by point counting using the method of Chayes (1956) as outlined in Flügel (2004). Point counting was carried out on individual size fractions, namely on $0.5 \varphi$ increments between -2 and $+0.5 \varphi$ fractions, of unconsolidated sediment samples viewed under a binocular microscope. On selected samples, in particular those in which most grain surfaces were abraded, point counting was also carried out on thin-sections of the bulk sediment prepared from grain mounts.

To determine quantitatively the contribution of terrigenous sediment to the system, concentrations of inorganic carbon (IC) were determined on splits of bleached samples using the coulometrics titration technique. This method involves acidification of a sample in a closed system and measurement of the concentration of carbon dioxide $\left(\mathrm{CO}_{2}\right)$ that is liberated by back-titrating to a coulometric endpoint. The percentage of carbonate in each sample reflects the amount of IC liberated as $\mathrm{CO}_{2}$, such that wt $\% \mathrm{CaCO}_{3}=$ $w t \%$ TIC $\times 8.332$ (where TIC is total inorganic carbon). All organic matter was removed during the bleaching process, allowing the concentration of terrigenous clastic sediment to be calculated as the amount of insoluble residue follow-

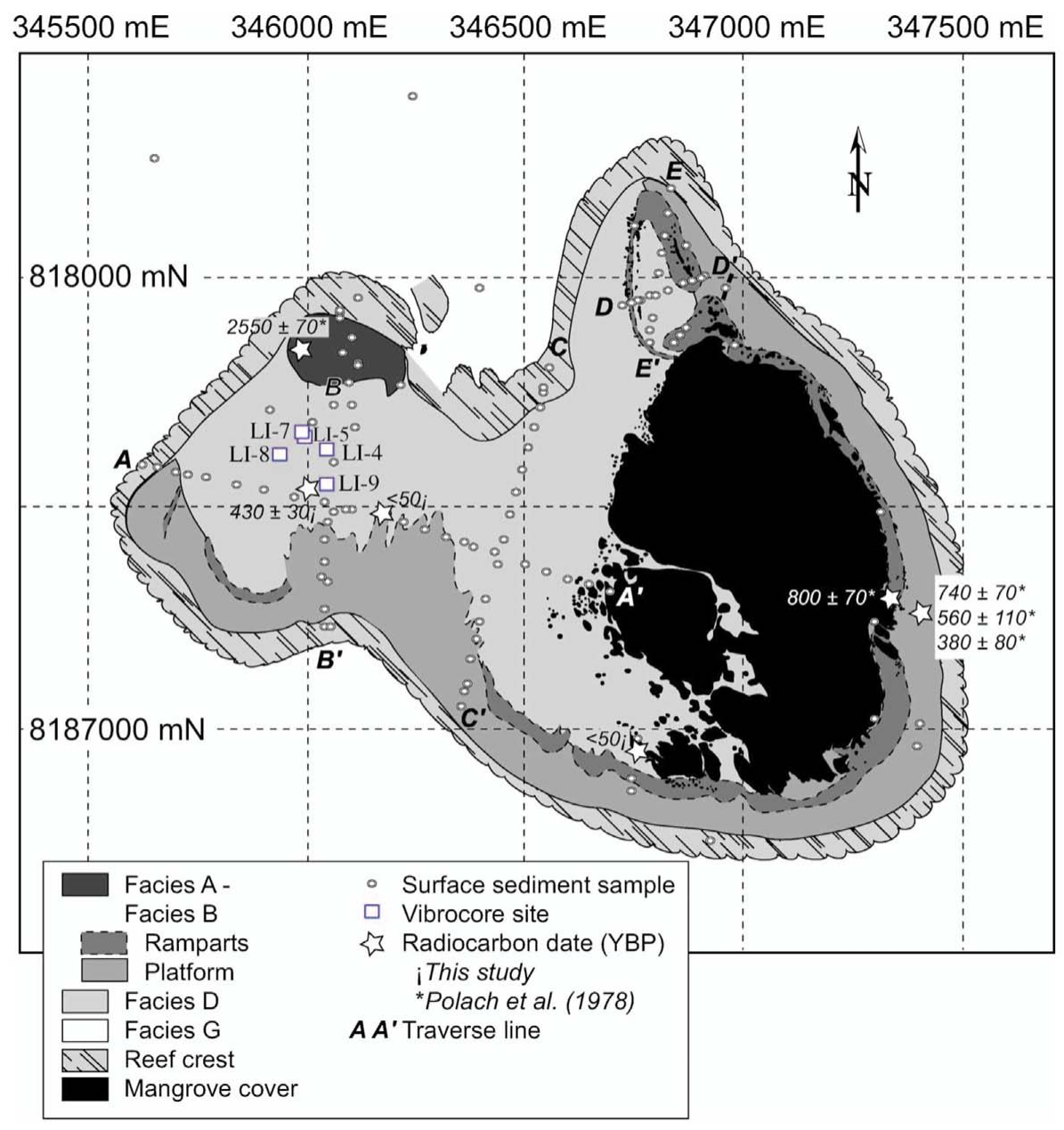

Figure 3. Facies map of Low Isles Reef showing sediment sampling locations, traverse lines, vibrocoring sites and radiocarbon ages of surface samples. The Universal Transverse Mercator (UTM) coordinates indicated on the map perimeter are in the Australian Geodetic Datum (AGS), 1984 system. 


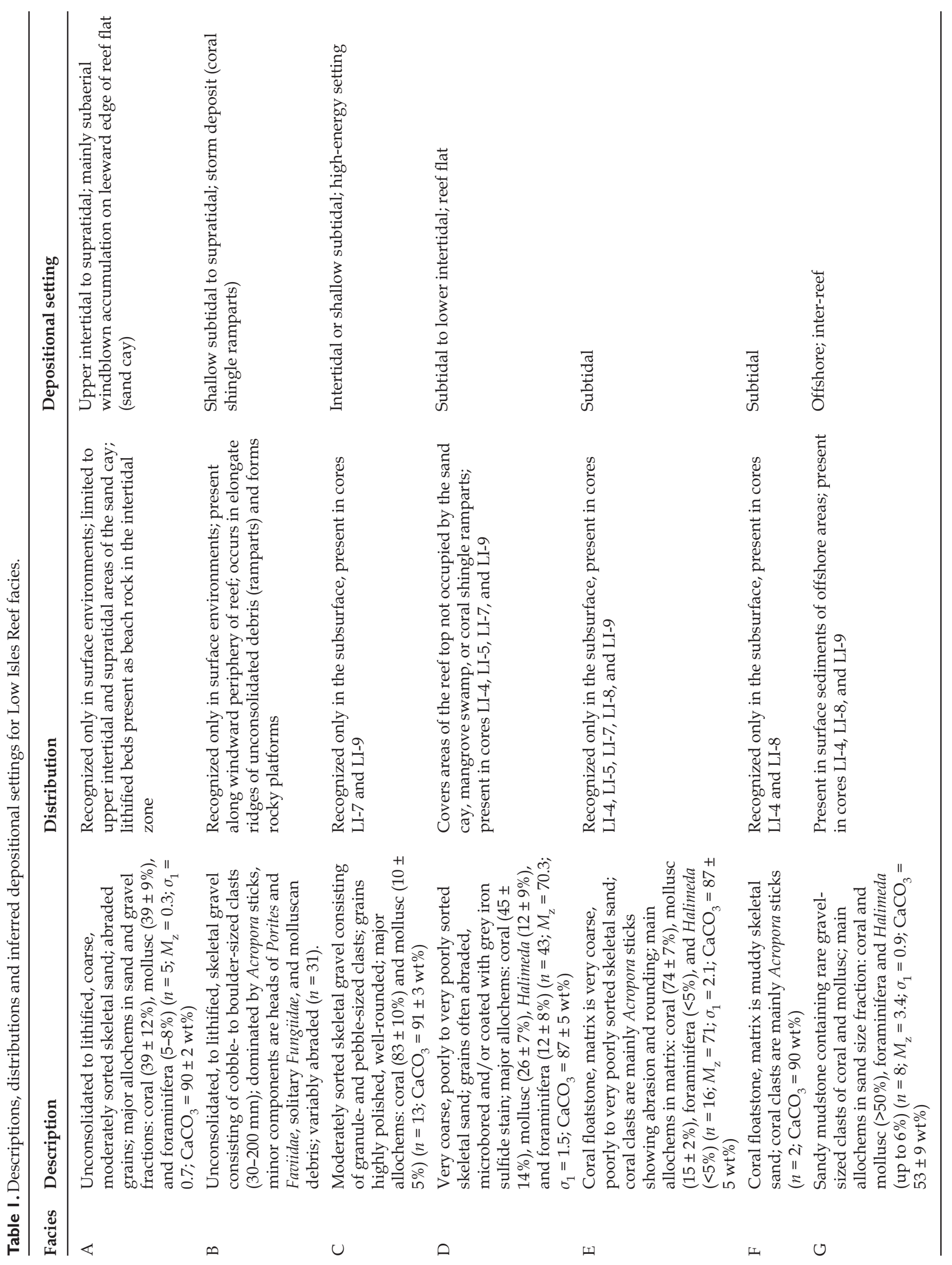


ing the acidification process. Precision is better than $0.5 \%$ and was monitored by multiple analyses of a pure carbonate laboratory standard.

\section{${ }^{14} \mathrm{C}$ dating}

Carbonate components from unconsolidated surface and subsurface sediments were collected for age determinations using accelerator-mass spectrometry (AMS) by Beta Analytic (Miami, FL). Samples were examined under the binocular microscope to assess the level of physical and chemical alteration. Only samples that showed no evidence of recrystallization were selected for analysis. However, the selected samples showed a range of physical alteration, from pristine to highly abraded. Benthic foraminifera were chosen because of their calcitic shell mineralogy, which is relatively resistant to chemical alteration. Foraminiferan tests were also considered ideal because of their tendency to accumulate in situ (i.e. undergo less post-mortem transport than other grain types: Jell et al. 1965), reflecting the relatively high production rate of these organisms and their tendency to live attached to algae that, in turn, serve to stabilize the substrate. Although an aragonitic mineralogy makes corals susceptible to diagenetic alteration, additional analyses were carried out on well-preserved fragments of Acropora.

Because of their small size and relatively pristine appearance, foraminifera did not require pre-treatment prior to analysis. Coral fragments were etched as necessary to remove outer abraded rinds and reveal a fresh interior. Results from the present study are reported in terms of the conventional ${ }^{14} \mathrm{C}$ age, determined by applying ${ }^{13} \mathrm{C} /{ }^{12} \mathrm{C}$ corrections to the measured age. Ages are reported with the units y BP (years Before Present), with Present defined as AD 1950. The modern reference standard was $95 \%$ of the ${ }^{14} \mathrm{C}$ content of the National Bureau of Standards Oxalic Acid calculated using the Libby ${ }^{14} \mathrm{C}$ half-life (5568 years). Quoted errors represent $1 \sigma$, based on combined measurements of the sample, background, and modern reference standards. Samples containing more ${ }^{14} \mathrm{C}$ than the modern reference standard indicate that the foraminifer was living after the advent of thermonuclear weapons testing and is $<50$ years old. The present study also incorporates previously published ${ }^{14} \mathrm{C}$ ages available in McLean et al. (1978) and Polach et al. (1978) (refer to these sources for details regarding methodology). Locations and ages of surface samples are indicated on Figure 3. The depths and ages of subsurface samples are indicated on Figure 4.

\section{Petrography}

Surface samples from the reef top are mud-poor and consist of variable mixtures of sand- and gravel-sized skeletal material. The reef flat is covered by poorly to very poorly sorted, very coarse skeletal sand containing up to

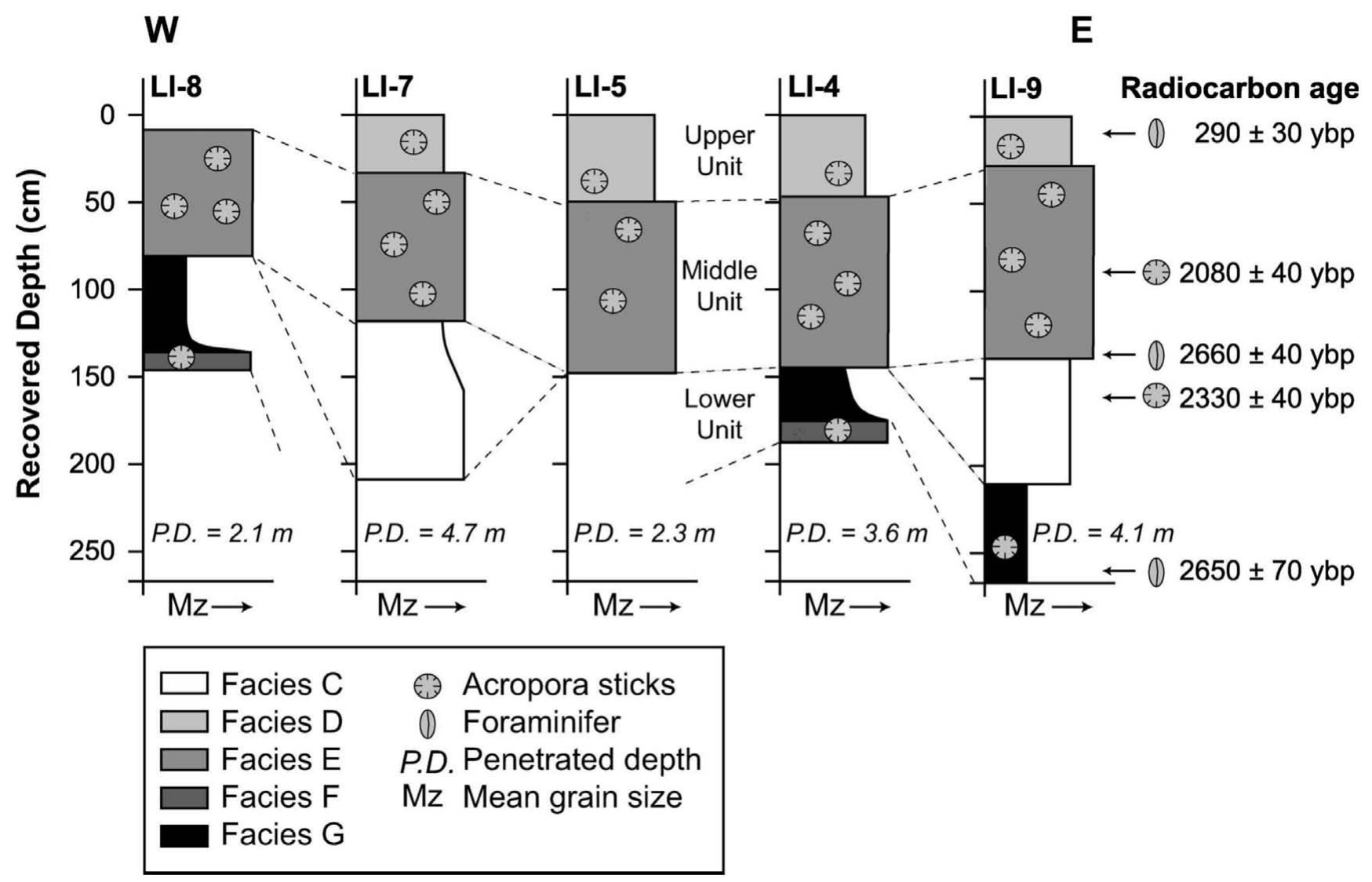

Figure 4 Graphic logs of vibrocores LI-4, LI-5, LI-7, LI-8 and LI-9, showing facies distributions, stratigraphic relationships, and depths and ages of samples collected for radiocarbon analysis. Also indicated are penetrated and recovered depths for each core. 
$13 \mathrm{wt} \%$ insoluble material. The main allochems in the sand and gravel size fractions are corals $(45 \pm 14 \%)$, followed by molluscs $(26 \pm 7 \%)$ and Halimeda plates and benthic foraminiferan tests, each of which typically comprises $\sim 12 \%$ of the grains in these samples $(n=43)$. Sediment of the sand cay is finer (medium sand) and better sorted $\left(\sigma_{1}=0.7 ; n=5\right)$. Point counting shows that the main allochems in sand cay sediments are coral debris $(39 \pm 12 \%)$, mollusc shell fragments $(39 \pm 9 \%)$, and benthic foraminifera $(5-8 \%)$. Sediments in offshore areas to the north of the reef consist of sandy mud, and contain a larger proportion of terrigenous clastic sediment $\left(\mathrm{CaCO}_{3}=53 \pm 9 \mathrm{wt} \%\right)$. The sand-size fraction in these samples $(n=2)$ is dominated by mollusc fragments $(\sim 50 \%)$, with coral debris, benthic foraminifera and insoluble material making up the remainder.

Subsurface lithologies are variable, ranging from mudfree gravel with highly polished grains, to muddy-to- sandy coral floatstone and sandy mud. The proportion of non-carbonate material in the subsurface samples ranges from close to zero in the mud-free, gravelly sediments to $25 \mathrm{wt} \%$ in floatstones and sandy muds $(n=47)$. Coral fragments are the dominant allochems in the sand and gravel fractions in the subsurface, making up an average of $75 \pm 10 \%$ of the sediment particles. Although mollusc shell debris, foraminifera, and Halimeda are also present in significant amounts (molluscs, $15 \pm 7 \%$; foraminifera and Halimeda, both $<4 \%$ ), these allochems are less prominent than in surface sediments.

\section{${ }^{14} \mathrm{C}$ Ages}

Pristine-looking foraminifera tests from the reef flat to the west of the mangrove swamp contained more ${ }^{14} \mathrm{C}$ than the AMS standard, suggesting that the foraminifera were living within the past 50 years. A highly abraded foraminifer collected from the reef flat to the south of the sand cay yielded an age of $430 \pm 30$ y BP (Figure 3). Subsurface samples for radiocarbon dating were collected from core LI-9, which is located on the western side of the reef flat and contains the thickest section (Figure 4). The shallowest sample, a foraminifer obtained from $15 \mathrm{~cm}$ depth, yielded an age of $290 \pm 30$ y BP. Samples of foraminifera and coral collected from $>50 \mathrm{~cm}$ depth returned ages between $\mathrm{ca} 2700$ and 2000 y BP. Previous work by Polach et al. (1978) indicated that sand cay sediments are $\sim 2550$ years old. Well-preserved sticks of Acropora from accumulations of unconsolidated coral rubble and cemented platforms of the windward reef flat yielded ages of ca 800-380 y BP (Polach et al. 1978).

\section{Facies and Facies Distribution}

Eight facies (Table 1) are recognized on the surface (Figure 3) and in the subsurface (Figure 4) of Low Isles Reef, based on variations in lithology. Facies A-E are skeletal sands and gravels; Facies F and G contain a significant proportion of terrigenous mud. Facies $\mathrm{A}$ and $\mathrm{B}$ are found only on the modern reef surface, whereas Facies C, E, and F only occur in cores. Facies D and $\mathrm{G}$ are present in both the surface and subsurface.

\section{Facies $A$}

Facies A consists of unconsolidated to fully lithified, coarse, moderately sorted skeletal sand. Its occurrence is limited to the modern sand cay, located on the leeward edge of the reef flat (Figure 3). As discussed above, the major skeletal components are fragments of coral and mollusc shells, which each make up $\sim 39 \%$ of the sediment. Foraminifer tests make up a minor proportion (5-8\%). With the exception of a few fresh-looking foraminifera, all grains in sand cay samples show signs of abrasion. Where lithified, Facies A forms irregular exposures of beachrock within the intertidal zone of the sand cay, which are oriented parallel to the edges of the cay. Eolian deposition in the upper intertidal to supratidal environment is inferred on the basis of the restriction of this facies to the sand cay, known from previous studies of platform cays to have formed by eolian processes (Flood 1974, 1977b). This interpretation is further supported by surface abrasion on grains and grainsize and sorting parameters that fall within the ranges expected for windblown material (Friedman 1961).

\section{Facies B}

Facies B, consisting of unconsolidated to fully lithified coral gravel (Table 1), is recognized on the windward periphery of the modern reef surface (Figure 3). The unconsolidated deposits form distinctive, elongate ridges, or ramparts, generally $0.5-2 \mathrm{~m}$ in height and $40-50 \mathrm{~m}$ in width, which are oriented parallel to the windward periphery of the modern reef surface. The ramparts are commonly asymmetric in cross-section, with short, steep inward-facing (leeward) sides that slope $\geq 45^{\circ}$ (Figure 5a) and long, gentle seaward-facing sides that slope $<10^{\circ}$ from horizontal (Figure $5 b$ ). The ramparts are substantial enough in terms of height and continuity to form continuous barriers that restrict drainage from the reef flat at low tide. The toes of former ramparts are visible as sets of lithified, elongate ridges (Figure 5c) referred to as "bassett edges" by previous workers (McLean \& Stoddart 1978). Lithification of the inwardfacing slopes of ramparts presumably occurred subtidally when the ramparts served as dams that restricted drainage from the reef top. Much of the windward side of the reef flat is underlain by a lithified pavement of Facies B (Figure $5 \mathrm{~d}$ ). This rocky platform extends for some distance (at least $100-150 \mathrm{~m}$ ) into the mangrove swamp.

The elongate accumulations of Facies B across shallow subtidal to supratidal depths along the windward margin of the reef are storm deposits (Frank \& Jell 2006). Under normal weather conditions, shingle accumulates in low banks just behind the reef crest. During heavy weather, the accumulated shingle and newly broken material is remobilized and deposited to form the ramparts (McLean \& Stoddart 1978). Abrasion of coral debris during storm transport imparts a white, bleached look to relatively recent deposits, making them readily identifiable in aerial photographs (Figures 2, 5a). By contrast, shingle accumulations that remain in place gradually turn grey and black as cyanobacteria colonize clast surfaces, and may ultimately be lithified. 

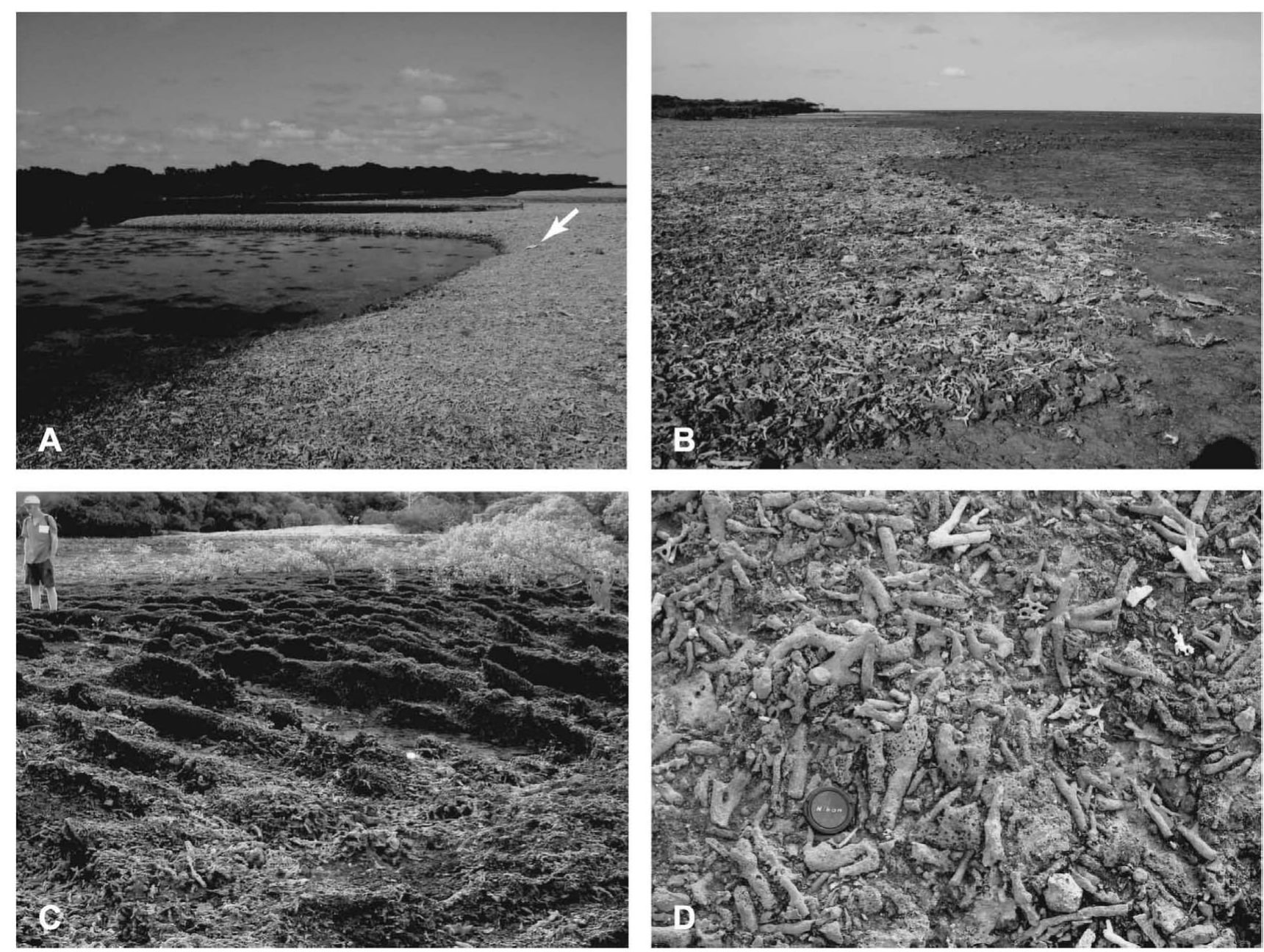

Figure 5. Characteristics of Facies B on Low Isles Reef. (a) Inner (north) edge of shingle rampart and adjacent subtidal pool on southern reef margin (dive slate, indicated by arrow is $20 \mathrm{~cm}$ wide). (b) Outer (south) edge of shingle rampart atop cemented equivalent on southern reef margin (largest coral pieces in foreground $15 \mathrm{~cm}$ in length). (c) Cemented toes of former shingle ramparts on eastern reef margin, forming a series of features termed "bassett edges" by previous workers. (d) Cemented pavement on eastern margin consisting of lithified coral debris (lens cap diameter is $4.5 \mathrm{~cm}$ ).

\section{Facies C}

Facies $\mathrm{C}$ occurs in the subsurface, and has been recognized in cores LI-7 and LI-9. This facies consists of moderately sorted skeletal gravel (Table 1). Clasts range from granule to pebble sizes and are well rounded and highly polished (Figure 6). Coral and mollusc fragments are the major components, making up $83 \pm 10 \%$ and $10 \pm 5 \%$ of grains, respectively. Based on the absence of mud-sized material and the polished nature of the grains, Facies $C$ is interpreted to record deposition under high-energy conditions such as the intertidal or shallow subtidal zones, where grains would be subject to frequent reworking by waves.

\section{Facies D}

Facies $\mathrm{D}$ is the most prominent facies, covering large portions of the reef top (Figure 3). It is present on all areas of the reef surface not otherwise occupied by the sand cay, mangrove swamp, shingle ramparts, or lithified pavements. Fa- cies $\mathrm{D}$ is also recognized in cores LI-4, LI-5, LI-7, and LI-9 (Figure 6). This facies consists of very coarse, poorly to very poorly sorted skeletal sand containing fragments of coral (45 $\pm 14 \%)$, mollusc $(26 \pm 7 \%)$, Halimeda (12 $\pm 9 \%)$ and foraminifera $(12 \pm 8 \%)$ (Table 1$)$. Grains often have a blackened appearance due to staining of grain surfaces. Thin-section examination reveals that all grains, with the exception of a few foraminifera, have been subjected to microboring by endolithic algae. The current distribution of Facies D and the extensive microboring of grains observed in thin-section is interpreted to reflect deposition in subtidal to lower intertidal areas of the reef flat (Bathurst 1975).

Facies $E$

Facies E, sandy coral floatstone, occurs in cores LI-4, LI5, LI-7, and LI-9 (Table 1). Coral clasts are mainly 30-50 mm abraded sticks of Acropora. The matrix, consisting of grey, poorly to very poorly sorted, very coarse skeletal sand, has been heavily microbored (Figure 6). Although strikingly 


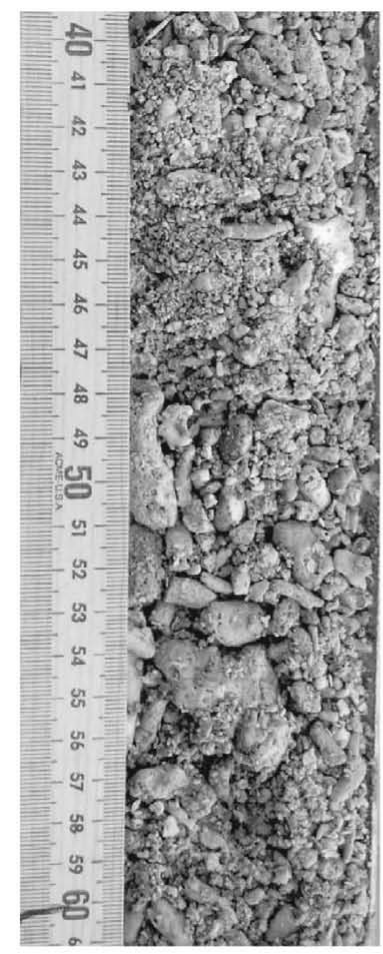

Facies C

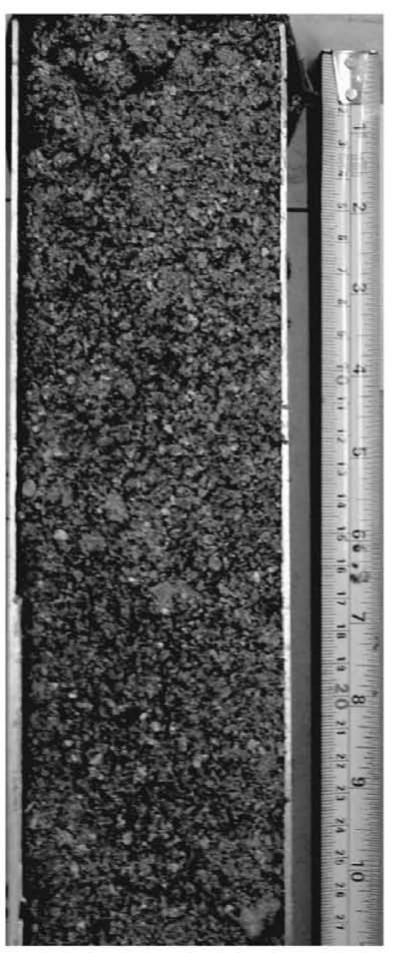

Facies D

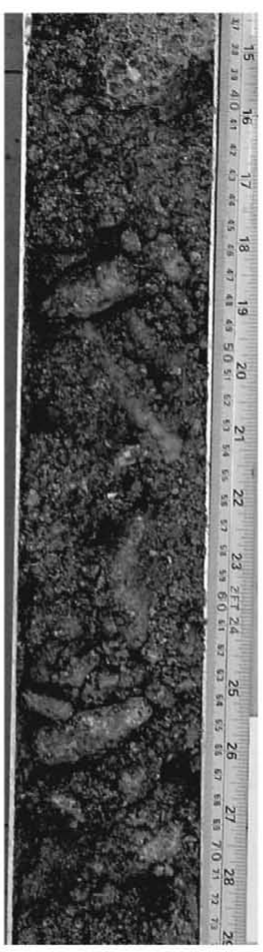

Facies E

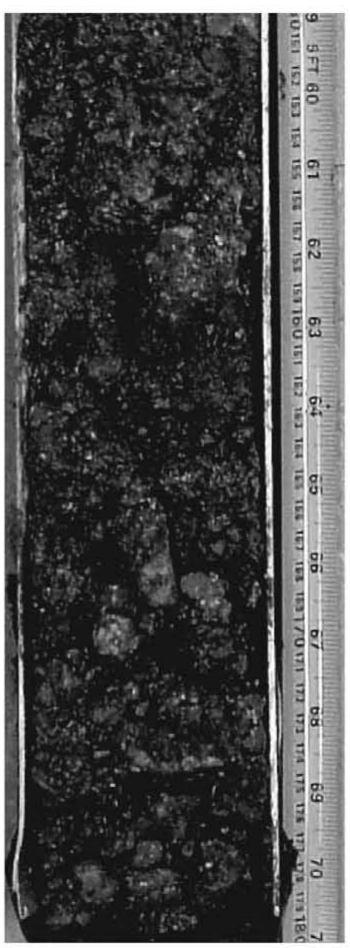

Facies $\mathrm{F}$

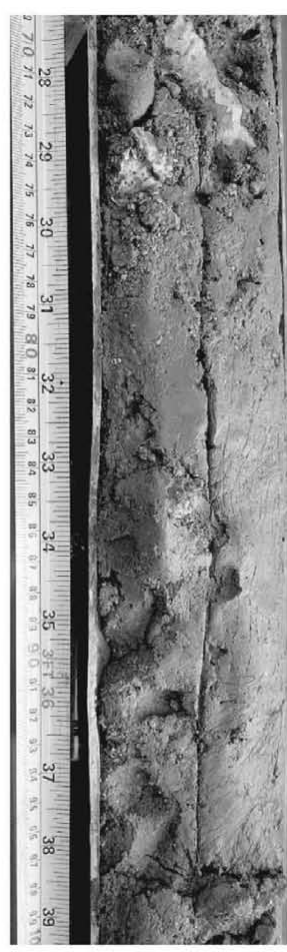

Facies G

Figure 6. Vibrocores showing (from left to right) moderately sorted, polished skeletal gravel of Facies C; very coarse, poorly to very poorly sorted skeletal sand of Facies D; coral floatstone with a skeletal sand matrix of Facies E; coral floatstone with a matrix of muddy skeletal sand, Facies F; and sandy mudstone of Facies G.

similar in overall appearance to Facies D, the skeletal composition of the matrix differs significantly. Relative to Facies $\mathrm{D}$, coral fragments are more prominent, making up 74 $\pm 7 \%$ of the grains, and other allochems, including mollusc debris $(15 \pm 2 \%)$, foraminifera $(<5 \%)$ and Halimeda plates $(<5 \%)$, occur in lesser amounts. The presence of coral clasts and extensive microboring suggests that Facies E reflects deposition in subtidal areas of the reef flat.

\section{Facies $F$}

Facies $\mathrm{F}$ is a subsurface facies recognized in cores LI4 and LI-8. It consists of coral floatstone with a matrix of muddy skeletal sand (Figure 6). Coral, mainly Acropora, fragments exhibit variable amounts of abrasion, with some fragments appearing fresh. The presence of mud in this facies suggests deposition in relatively quiet, subtidal conditions.

\section{Facies $G$}

Facies $\mathrm{G}$ occurs in offshore areas to the north of the reef, and in cores LI-4, LI-8, and LI-9. Facies G is a sandy mudstone that contains rare gravel-sized pieces of coral and mollusc shells (Figure 6). This facies contains up to $50 \%$ terrigenous clastic sediment. The dominant allochems are corals and mollusc debris, together comprising $>50 \%$ of the sand fraction, with foraminifera and Halimeda occurring in variable amounts. The abundance of mud-sized material and present conditions offshore suggest that Facies G records deposition in relatively deep ( 10-15 m) water.

\section{Stratigraphy}

Inferred stratigraphic relationships (Figure 4) are based on the recognition of the facies described in the previous section in cores drilled into the reef flat south of the sand cay. It is assumed that while some facies occur in a sheet-like geometry, small topographic variations and storm erosion and deposition can lead to significant lateral facies variations. Such lateral facies variations are evident on the modern reef surface (Figure 3). The subsurface stratigraphy consists of three laterally continuous units that overlie a surface at 410$470 \mathrm{~cm}$ depth, which the vibrocoring system was unable to penetrate. Deformation of the aluminum pipes that came into contact with the surface suggests that it is well lithified. These units record a gradual shoaling from offshore (offreef) to intertidal depths. A fourth unit, consisting of polished coral gravel of Facies C, was recovered in cores LI-7 and LI-9 and appears to be laterally discontinuous.

The lowermost unit, recovered in cores LI-8, LI-4, and LI-9, consists of Facies F and Facies G, and records deposition at subtidal depths equivalent to the modern offshore. Sediments contain a high proportion of terrigenous mud, presumably derived from surrounding areas of the shelf. This unit contains minor coral, primarily sticks of Acropora, and mollusc debris. The coral debris is variably pre- 
served, with some clasts appearing fresh and others highly abraded. The presence of the fresh-looking debris suggests active coral growth in nearby areas, and occasional breakage and transport of coral debris to the coring sites. Radiocarbon dating of a fresh-looking piece of coral from this unit yielded an age of $2650 \pm 70 \mathrm{y}$ BP. The worn fragments of coral are presumably older and might include relict Pleistocene sediment.

The middle unit, consisting of Facies E, was recovered in all cores (Figure 4). The paucity of mud-sized material in this unit suggests that it records deposition in shallower waters than the underlying unit, at depths where mud was largely removed by the winnowing actions of waves and currents. This unit is characterized by an increased diversity in grain types. Grains have been abraded, fragmented and microbored, suggesting reworking during a lengthy residence time in the shallow subtidal environment. A well-preserved foraminifer collected from the base of this unit in core LI-9 returned an age of $2660 \pm 40$ y BP. A coral recovered from the middle of the unit, $\sim 100 \mathrm{~cm}$ depth in core LI-9, yielded an age of $2080 \pm 40$ y BP.

The middle unit is sharply overlain by an upper unit consisting of Facies D, which records deposition under subtidal to intertidal conditions similar to those that characterize the modern reef flat. The unit is homogeneous, with no sedimentary structures, including bioturbation features, evident. Homogenization of this unit is confirmed by ${ }^{14} \mathrm{C}$ ages derived from individual foraminifera. Samples collected from the surface yield radiocarbon ages ranging from 480 to $<50$ y BP; a sample from $20 \mathrm{~cm}$ depth in core LI-9 returned an age of $290 \pm 30$ y BP. The exteriors of individual grains are worn and/or exhibit evidence of extensive microboring, suggesting a lengthy residence time on the reef flat. These characteristics suggest that the unit represents the depth to which sediments have undergone reworking by waves and currents, in particular those generated during storms.

In addition to the three units described above, which record gradual shoaling, a fourth unit consisting of Facies $C$ was recovered at depth in cores LI-7 and LI-9 (Figure 4). The unit is homogeneous, consisting of moderately sorted skeletal gravel. Unlike the enclosing facies, which are grey in color, this unit exhibits a buff color. Facies $C$ has a lower proportion of mud than facies that occur in the subsurface, and grains appear highly polished. These characteristics suggest deposition in a high-energy, wave-washed environment, in which grains were frequently rolled and abraded and the smaller size fractions were winnowed away. This discontinuous unit is interpreted to record gravel shoals on topographic highs, possibly deposited by one or more storm events. A coral fragment from this unit returned a radiocarbon age of $2330 \pm 40 \mathrm{y} \mathrm{BP}$.

\section{Discussion}

Radiocarbon dates from core LI-9 (Figure 4) and surface samples (Figure 3) provide insight into the ages of the stratigraphic units and thereby the timing of reef develop- ment. However, given the low sample size and the clastic nature of the deposits, the effect of time-averaging resulting from reworking of unconsolidated skeletal material must be considered (Kowalewski \& Bambach 2003). Although high rates of sediment production by reef-dwelling organisms make the effect of time-averaging on coral reef settings lower than in siliciclastic environments (Kidwell et al. 2005), vertical mixing may extend the age range of shells within a given stratigraphic interval to several hundred years. Such processes may explain why the ${ }^{14} \mathrm{C}$ ages of components analyzed in core LI-9 do not systematically increase with depth (Figure 4). However, the clear distinction in ${ }^{14} \mathrm{C}$ ages derived from the lower and middle stratigraphic units (3000-2000 y BP) vs those obtained from the upper unit and surface sediments $(<800$ y BP) suggests that broad age groupings may be used to provide temporal constraints on reef evolution, as discussed below.

Radiocarbon dates from the lower stratigraphic unit and Facies $C$ suggest that Low Isles Reef began forming around 3000 y BP atop a hard substrate, now at $\sim 450 \mathrm{~cm}$ depth, that was not penetrable by vibrocoring (Figure 7). This juvenile stage is recorded by the lowermost unit, which is dominated by terrigenous mud (Facies G) derived from the surrounding shelf. Well-preserved coral fragments in this unit suggest active coral growth in the vicinity, presumably around the margins of what would ultimately become the Low Isles Reef lagoon. Many inner and middle shelf reefs of the Great Barrier Reef with the classical "bucket" shape of Schlager (1981) initiated atop Pleistocene reefs that underwent subaerial exposure and karsting during the last glacial maximum at $\mathrm{ca} 18 \mathrm{ka}$. Karsting was relatively intense in central portions of the reef top, ultimately causing the development of central depressions in exposed platforms. Reef growth following the subsequent sea-level rise mimicked the resulting topography, such that the early stage of vertical growth tended to occur around the elevated rims of the antecedent reefs (Hopley 1982).

The middle stratigraphic unit, deposited between $c a$ 2600 and 2000 y BP, is interpreted to record deposition in a shallow central lagoon during the mature (Hopley 1982) stage of reef development, when Low Isles Reef was at its most productive (Figure 7). A decrease in the proportion of mud-sized material suggests that the sediment surface had reached shallow subtidal depths, and was subject to the sorting action of waves and currents. The presence of mature reef flats, which contributed sediment to the central lagoon, is indicated by an increase in the diversity of skeletal grains (higher contributions from foraminifera and coralline algae) in this unit, recorded by Facies E. A radiocarbon date from the sand cay (ca 2500 y BP: Polach et al. 1978) suggests that parts of Low Isles Reef were emergent by this time.

The modern surface of Low Isles Reef, together with the relatively thin, upper stratigraphic unit, is interpreted as recording the senile (Hopley 1982) stage of reef development, characterized by complete infilling of lagoons and the contraction of most carbonate production to reef margins (Figure 7). The change in the locus and style of carbonate production is also reflected in the skeletal composition of the 
sand and gravel size fractions of Facies D. Relative to Facies E, which comprises the middle stratigraphic unit, Facies D contains a smaller proportion of corals and larger proportions of organisms that inhabit shallow, sandy areas of the reef flat, namely molluscs, Halimeda, and benthic foraminifera that live attached to algae (Table 1). The wide range of radiocarbon dates from this unit (ca $500 \mathrm{y}$ BP to present) and the deteriorated appearance of grains, due mainly to physical abrasion and microboring, suggest a dominance of destructive over constructive reef processes, namely reworking of existing sediment and minimal production of new carbonate. Radiocarbon ages from coral debris on the windward reef flat suggest that storm-generated shingle beaches or ramparts formed and/or were extended during this interval. The absence of material dated between ca 2000 and 800 y BP makes it difficult to constrain temporally when Low Isles Reef made the transition between the mature and senile stages of development, although the age gap may reflect the timing of the transition itself. Given evidence that the system became dominated by destructive sedimentary processes, it is likely that older sediment particles that formed during the transition have been destroyed, such that the current population of particles is biased toward younger grains (Kowalewski \& Bambach 2003).

\begin{tabular}{|l|}
\hline$\square$ Reef limestone \\
Facies D \\
$\square$ Facies E \\
Facies F \\
Facies G \\
Branching coral \\
a Digitate-encrusting corals \\
Reef flat dweller (mollusc, \\
Halimeda, benthic foraminifer, \\
etc.)
\end{tabular}

Figure 7. Schematic diagrams illustrating the growth stages and factors that controlled the development of Low Isles Reef. (a) Time 1 (>4000 y BP): reef growth inhibited by wetter climate conditions that increase sediment yields to the Queensland shelf. (b) Time 2 (ca 3000 y BP): initiation of vertically directed coral growth following change to drier, ENSO-dominated climate; Facies $\mathrm{F}$ and $\mathrm{G}$ deposited during juvenile stage of reef development. (c) Time 3 (3000-2000 y BP): maximum productivity on Low Isles Reef; reef flats contribute sediment to lagoon (Facies E), reflecting mature stage of reef development; sand cay and ramparts develop on reef top; sea-level dropping from $+1 \mathrm{~m}$ above present to present datum. (d) Time 4 (<20000 y BP): lagoon completely infilled as sea-level reaches modern elevation, storm erosion and deposition are dominant sedimentary processes; expansion of mangrove swamp and vegetation of sand cay; senile stage of reef development.
NW

SE

TIME 1 (>4000 YBP)

Sea level $+1 \mathrm{~m}$

Pluvial climate phase

Turbid water column

Eutrophic conditions?

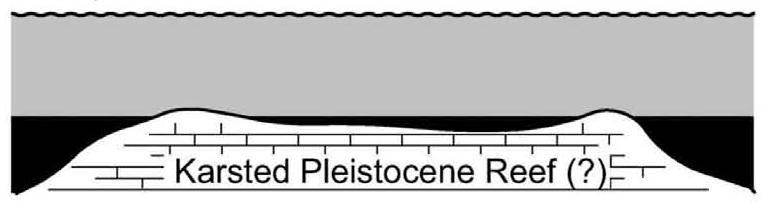

TIME 2 ( 3000 YBP)

Sea level $+1 \mathrm{~m}$

ENSO climate phase

Deposition of bottom stratigraphic unit (Facies F \& G)

Juvenile stage of reef development

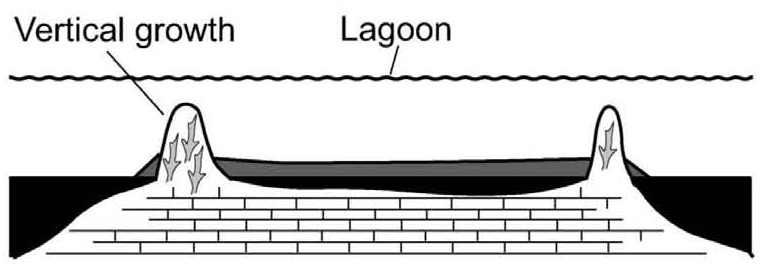

TIME 3 (3000-2000 YBP)

Sea level +1 to $0 \mathrm{~m}$
ENSO climate phase
Deposition of middle stratigraphic unit (Facies E)
Mature stage of reef development

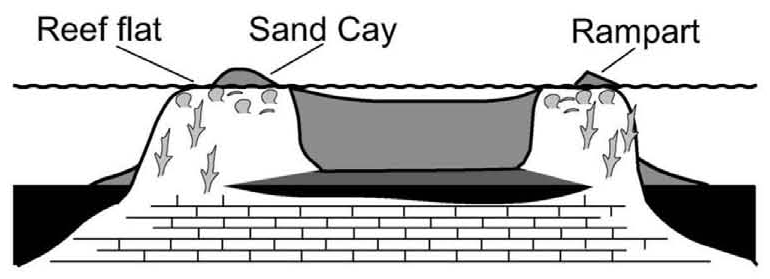

TIME 4 ( $<2000$ YBP)

Sea level $0 \mathrm{~m}$

ENSO climate phase

Deposition of upper stratigraphic unit (Facies D)

Senile stage of reef development

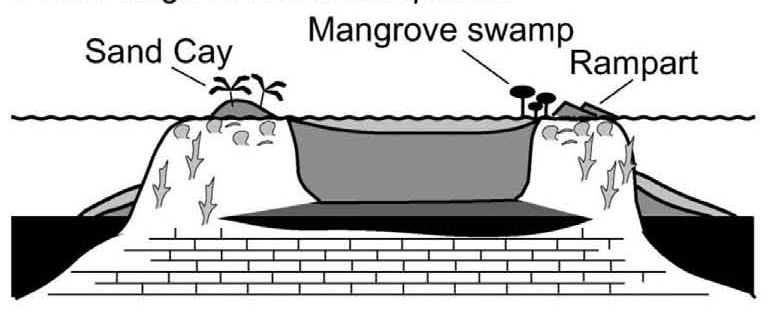




\section{Controls on reef development}

The Holocene history summarized in the previous section suggests that Low Isles Reef was at its most productive between $\mathrm{ca} 3000$ and $2000 \mathrm{y} \mathrm{BP}$, and reached its current senile state soon after. It is tempting to interpret the shallowing-upward sequence evident in the subsurface stratigraphy in terms of progressive infilling of accommodation space following a lag time in the wake of the postglacial sea-level rise beginning at ca $18000 \mathrm{y} \mathrm{BP}$ and the subsequent highstand at $c a 6000 \mathrm{y} \mathrm{BP}$. However, several lines of evidence suggest that regional, post-highstand changes in sea-level and variations in the Holocene climate of northeastern Australia strongly impacted the development of Low Isles and similar reefs of the northern Great Barrier Reef.

\section{Sea-Level}

Global sea-level records suggest that modern sealevel was reached at ca 6000 y BP. However, evidence from coastal marine sediments and reefs in northeastern Queensland (McLean et al. 1978; Johnson \& Carter 1987; Larcombe et al. 1995) suggests that sea-level rose again in this region, reaching $+1 \mathrm{~m}$ above present sea-level by $c a$ 5500 y BP. The higher sea-level persisted until ca 3000 y BP, before dropping again and stabilizing at modern levels by 2000 y BP. Radiocarbon and stratigraphic data from Low Isles suggest that the main period of reef productivity occurred almost exclusively within that window of time.

This temporal pattern has been noted on other inner to mid-shelf reefs of the northern Great Barrier Reef by McLean et al. (1978) and Polach et al. (1978), who compiled radiocarbon data derived from surface deposits, including sand cays, microatolls and shingle ramparts. The data from sand cays fell into two groups: (i) larger cays that lie at elevations above the limit of current cay sedimentation that yielded ages of 4000-3000 y BP; and (ii) smaller cays of lower elevation that are in equilibrium with current conditions, including the Low Isles cay, with ages of 3000-2000 y BP. The larger cays, now inactive, are inferred to have formed when the sea level was higher than present. The smaller cays, on the other hand, formed as the sea-level dropped. They remain in equilibrium with current depositional conditions, and so are subject to reworking by wind and waves (Flood 1977a). Cemented ramparts, which now form wave-swept platforms on the windward flats of Low Isles and other low-wooded island reefs, also yielded ages between 4000 and 2000 y BP (McLean et al. 1978). Together, sand cays and shingle ramparts record the emergence of reefs as coral growth reached sea-level, enabling the development of extensive reef flats.

The relative dearth of material younger than 2000 y BP on Low Isles Reef is a characteristic common to much of the Great Barrier Reef (McLean et al. 1978; Marshall \& Davies 1982; Johnson et al. 1984; Chivas et al. 1986; Smith et al. 1998). The few younger samples from Low Isles Reef were obtained from clasts of windward shingle ramparts, which owe their origin to storm activity, and benthic foraminifera, which reproduce annually and have plenty of habitat in the form of algae and sea-grass meadows that occupy subtidal ponds. Taking the enduring actions of storms and the continued presence of foraminiferal habitats into account, it is evident that soon after 2000 y BP, the sedimentary regime on Low Isles Reef shifted from one dominated by depositional processes (i.e. carbonate production) to present conditions, which are dominated by sediment reworking, including shedding off the top of the reefed area. The timing of the shift implies that although minimal, the drop in sealevel exposed the reef top, and effectively shut off the shallow subtidal carbonate factory. The degree to which accommodation space is filled on this reef is evident during low spring tides, when much of the reef flat and crest is exposed (Figure 8).

\section{Climate}

Although it is clear that the sea-level exerted a strong control on the decline of carbonate productivity on Low Isles Reef, factors that controlled the onset of carbonate production at $c a 3000$ y BP remain unclear. Given that the sea-level had already been $+1 \mathrm{~m}$ higher for roughly 2500 years, what accounts for the delay in carbonate productivity on Low Isles and other nearby reefs? One issue that has not been widely considered in the context of controls of the Holocene development of the Great Barrier Reef is climate change, in particular changes in rainfall patterns and the flux of terrigenous sediment to the Queensland shelf.

Several independent lines of evidence indicate that tropical regions of northern Australia were wetter in the Early Holocene (ca 12 000-4000 y BP) and have become drier subsequently. The independent datasets include pollen records (Kershaw 1978; Shulmeister 1992), paleo-plunge-pools that are out of equilibrium with modern waterfall discharge (Nott \& Price 1994), and stratigraphic data from alluvial (Wyrwoll \&Miller 2001), arid lake (Magee et al. 2004), and river delta (Fielding et al. 2006) deposits. The wetter pluvial period, which apparently characterized the entire Asia-Pacific region, has been attributed to a strengthened summer monsoon and a suppressed El Niño-Southern Oscillation (ENSO) relative to today (Clement et al. 2000; Goodbred \& Kuehl 2000; Wyrwoll \& Miller 2001; Magee et al. 2004; Bookhagen et al. 2005; Miller et al. 2005).

The temporal coincidence between the transition from wetter to drier conditions and the onset of elevated carbonate productivity implicates a climate control on reef development on the inner to middle shelf of the Great Barrier Reef. Under the current climate regime, the distribution of precipitation is strongly seasonal and strongly controlled by the distribution and paths of tropical cyclones and the development of monsoon troughs. The prevailing southeasterly winds maintain a strong northwesterly current along the shoreface and inner shelf (Hopley 1982), which inhibits the dispersal of terrigenous sediment across the shelf (Larcombe \& Woolfe 1999; Orpin et al. 1999; Larcombe \& Carter 2004). Episodes of intense rainfall during the summer months (rainy season) result in rapid runoff, triggering short-lived, high-magnitude flooding events (Alexander et al. 1999). Often associated with, or responsible for, intense precipitation events are cyclones, which affect the northern Great Bar- 


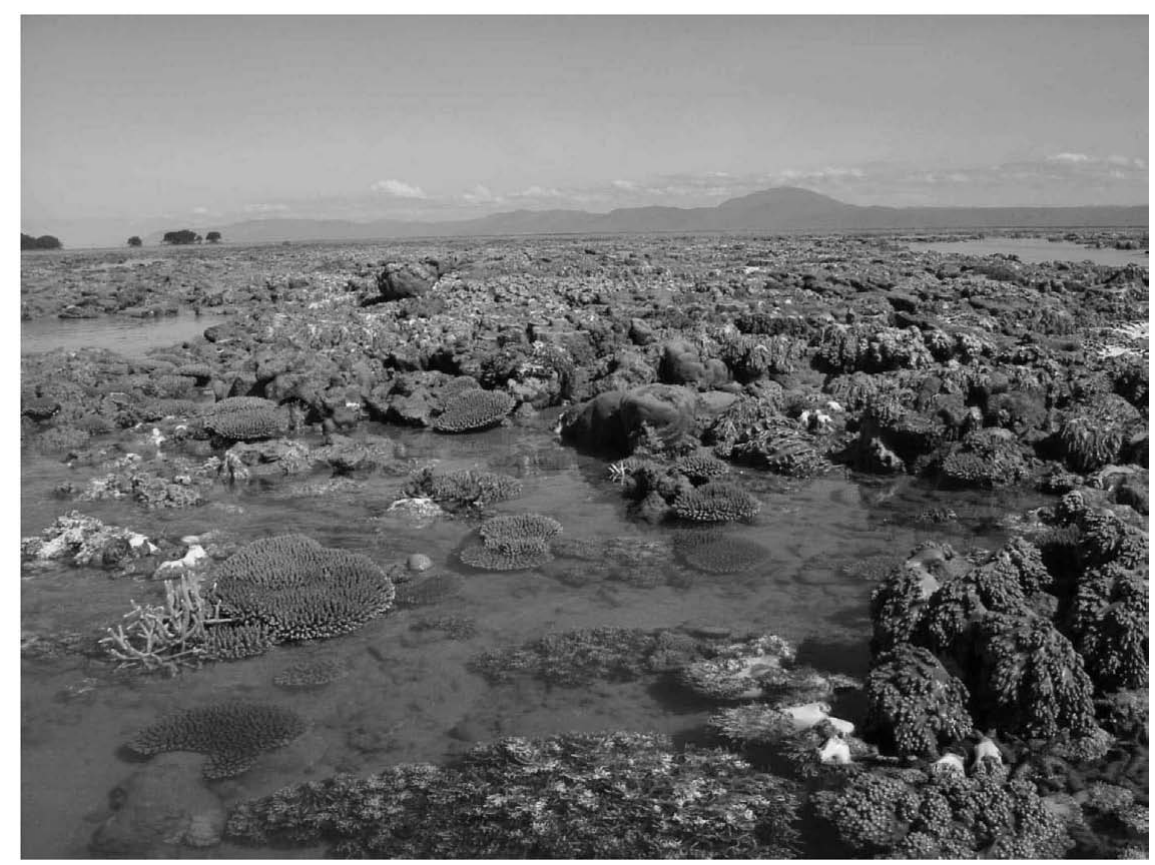

Figure 8. Westward (shoreward) view from the northern end of the mangrove swamp, showing exposed corals on the reef rim at low spring tide (June 2002). Field of view along lower edge of photograph is $2.4 \mathrm{~m}$.

rier Reef region every few years (Australian Bureau of Meteorology Cyclone Database: http://www.bom.gov.au/ weather/cyclones/tc-history.shtml). Cyclones may disrupt the prevailing wind systems, allowing flood plumes to extend across the inner shelf. First-hand accounts describe instances in which Low Isles Reef was overtopped by highly turbid, debris-laden flood plumes emanating from the Daintree River (Moorhouse 1936; Fairbridge \& Teichert 1948).

Stratigraphic data from the Burdekin River delta in northern Queensland suggest that sediment yields to rivers were higher during the Early Holocene pluvial phase, and resulted in an increased flux of terrigenous sediment to the Queensland shelf relative to today (Fielding et al. 2006). It is tempting to speculate that differences in the strength of prevailing wind systems affected the position and/or strength of the longshore current system, perhaps allowing terrigenous sediment to be dispersed across broader regions of the shelf. An additional possibility is that the nutrient load increased along with the sediment flux, rendering inner to mid shelf areas too eutrophic for corals to flourish. The shift from wet to dry, ENSO-dominated climate conditions after 4000 y BP coincides with a stratigraphic change from large to much smaller delta lobes of the Burdekin River, suggesting that sediment yield decreased as climate conditions became more arid (Fielding et al. 2006).

\section{Late Holocene history of Low Isles Reef}

Sea-level records from across the northern Queensland shelf indicate that the current datum $(0 \mathrm{~m})$ was attained ca 6000 y BP (McLean et al. 1978). Shortly after this point, the sea-level rose again, at least regionally, reaching an additional $+1 \mathrm{~m}$ above the present sea-level by ca 5500 y BP before dropping and stabilizing at $0 \mathrm{~m}$ between 3000 and
2000 y BP (Johnson \& Carter 1987; Larcombe et al. 1995). However, despite the availability of accommodation space, data from Low Isles Reef and other nearby reefs indicate that reef development in the region was delayed another 1500-2500 years. Similar studies of platform reefs of the main reef tract that formed where inter-reef sediments are carbonate-rich are few and largely restricted to the southern limit of the Great Barrier Reef (Marshall \& Davies 1982; Chivas et al. 1986; Smith et al. 1998). Limited radiocarbon data from these studies indicate that the latter reefs are significantly older than Low Isles, having initiated sometime before $c a 4200$ y BP and reached sea-level between $c a 5000$ and ca 3200 y BP (Smith et al. 1998).

Delayed reef development on Low Isles and other nearby reefs is attributed to the wetter climate conditions that characterized the Early Holocene ( $\mathrm{ca} 12,000-4000$ y BP) climate in this region (Nott \& Price 1994; Wyrwoll \& Miller 2001; Magee et al. 2004). Higher sediment yields and, possibly, nutrient loads to the Queensland shelf prior to $c a 4000$ y BP are postulated to have created turbid and/or euphotic conditions that inhibited significant carbonate production on the inner to middle shelf (Figure 7a). By contrast, carbonate production was not inhibited by terrigenous input in areas further offshore and along the main reef tract. As such, reef development began earlier, with individual platforms reaching sea-level before the main phase of reef development on inner to mid-shelf regions off far north Queensland.

The main phase of reef growth on Low Isles began $c a$ 3000 y BP (Figure $7 \mathrm{~b}$ ), in the wake of the transition from moist, humid conditions that characterized the Early Holocene to the arid, ENSO-dominated climate of the present and as the sea-level began to drop from $\mathrm{p} 1 \mathrm{~m}$ above present. Fielding et al. (2006) noted a concurrent drop in the riverine sediment flux to the Queensland shelf, evident as a 
decrease in the size of delta lobes of the Burdekin River. The coincidence between these factors suggests that environmental changes led to the development of conditions favorable for carbonate production (i.e., lower turbidity, nutrient levels).

Low Isles Reef flourished during a short window of time at 3000-2000 y BP, as the sea-level fell from +1 to $0 \mathrm{~m}$ above present (Figure 7c). This interval saw coral growth reach the sea-level and the development of mature reef flats, which contributed sediment to an interior lagoon. However, once the sea-level dropped to its present height, limited accommodation space led to a near-cessation of carbonate production across much of the reef top (Figure $7 \mathrm{~d}$ ). The character (geomorphology) of the reef top is now controlled largely by the actions of storms, including breakage of coral and transport of the resulting debris from the reef front to the reef flat (Frank \& Jell 2006), and remobilization of existing sediment across the reef top, in some cases with erosion to depths exceeding $\sim 50 \mathrm{~cm}$.

\section{Conclusions}

Data from Low Isles Reef enhance genetic models of reef development in the Great Barrier Reef region based on variations in the morphology of reefs across the Queensland shelf (Hopley 1982 and references therein). However, whereas such models have implicated sea-level as the major governing factor in reef development, results of the present study also reveal a strong link with regional climate. Whereas it appears that, once initiated, reefs undergo similar stages of development, data from broader regions of the Great Barrier Reef Province must be acquired before the Holocene history of reef growth on this classic carbonate platform is fully understood.

\section{Acknowledgments}

This project was supported by the Australian Research Council (Small Grant to TDF). Fieldwork and sample collection were carried out at the University of Queensland (UQ) Low Isles Research Station under Marine Parks Permit No. G01/270. I am extremely grateful to J. Jell, E. Frankel, and K. Firkins for fruitful discussions and for making it possible to recover an excellent set of vibrocores under difficult field conditions. I also thank G. Llyffe (Great Barrier Reef Marine Park Authority) and S. Corrie (UQ Centre for Marine Studies) for assistance with field logistics, and Quicksilver (Port Douglas, Queensland, Australia) for providing water transport between Port Douglas and Low Isles Reef. Reviews by R. Carter and J. Pandolfi significantly improved the paper.

\section{References}

Alexander J., Fielding C. R. \& Pocock G. D. 1999. Flood behaviour of the Burdekin River, tropical north Queensland, Australia. In: Alexander J. \& Marriott S. B. eds. Floodplains. Interdisciplinary Approaches, pp. 27-40. Geological Society of London Special Publication 163.
Bathurst R. G. C. 1975. Carbonate Sediments and their Diagenesis (2nd enlarged edition, Developments in Sedimentology 12). Elsevier, Amsterdam.

Belperio A. P. 1983. Terrigenous sedimentation in the central Great Barrier Reef lagoon: a model from the Burdekin region. BMR Journal of Australian Geology E Geophysics 8, 179-190.

Bennett I. 1971. The Great Barrier Reef. Lansdowne, Melbourne.

Bookhagen B., Thiede R. C. \& Strecker M. R. 2005. Late Quaternary intensified monsoon phases control landscape evolution in the northwest Himalaya. Geology 33, 149-152.

CHAYES F. 1956. Petrographic Modal Analysis. Wiley, New York.

Chivas A., Chappell J., Polach H., Pillans B. \& Flood P. 1986. Radiocarbon evidence for the timing and rate of island development, beach rock formation, and phosphatization at Lady Elliot Island, Queensland, Australia. Marine Geology $69,273-287$.

Clement A. C., Seager R. \& Cane M. A. 2000. Suppression of El Niño during the mid-Holocene by changes in Earth's orbit. Paleoceanography 15, 731-737.

Fairbridge R. W. 1950. Recent and Pleistocene reefs of Australia. Journal of Geology 58, 330-401.

Fairbridge R. W. 1967. Coral reefs of the Australian region. In: Jennings J. N. \& Mabbutt J. A. eds. Landform Studies from Australia and New Guinea. pp. 386-417. ANU Press, Canberra.

Fairbridge R. W. \& Teichert C. 1948. The Low Isles of the Great Barrier Reef: a new analysis. Geographical Journal 111, 67-88.

Fielding C. R., Trueman J. D. \& Alexander J. 2006. Holocene depositional history of the Burdekin River Delta of northeastern Australia: a model for a low-accommodation, highstand delta. Journal of Sedimentary Research 76, 411-428.

Flood P. G. 1974. Sand movements on Heron Island-a vegetated sand cay, Great Barrier Reef province, Australia. Proceedings of the 2nd International Coral Reef Symposium 2, 387-394.

Flood P. G. 1977a. The three southernmost reefs of the Great Barrier Reef Province-an illustration of the sequential/ evolutionary nature of reef type development. In: Day R. W. ed. Lady Elliot Island, Fraser Island, Gayndah, Biggenden, pp. 37-45. Geological Society of Australia, Queensland Division, Field Conference Guide.

Flood P. G. 1977b. Coral cays of the Capricorn and Bunker Groups, Great Barrier Reef province, Australia. Atoll Research Bulletin 195, 1-7.

Flood P. G. \& Orme G. R. 1977. A sedimentation model for platform reefs of the Great Barrier Reef, Australia. Proceedings of the 3rd International Coral Reef Symposium 2, 111-117.

Flood P. G., Orme G. R. \& Scoffin T. P. 1978. An analysis of the textural variability displayed by inter-reef sediments of the impure carbonate facies in the vicinity of the Howick Group. Philosophical Transactions of the Royal Society of London A291, 73-83.

Flügel E. 2004. Microfacies of Carbonate Rocks: Analysis, Interpretation, and Application. Springer, Berlin.

Folk R. L. 1974. Petrology of Sedimentary Rocks. Hemphill, Austin, TX.

Frank T. D. \& Jell J. S. 2006. Recent developments on a nearshore, terrigenous-influenced reef: Low Isles Reef, Australia. Journal of Coastal Research 22, 474-486. 
Friedman G. M. 1961. Distinction between dune, beach, and river sands from their textural characteristics. Journal of Sedimentary Research 31, 514-529.

Goodbred S. L. Jr. \& Kuehl S. A. 2000. Enormous GangesBrahmaputra sediment discharge during strengthened early Holocene monsoon. Geology 28, 1083-1086.

Gornitz V. 1993. Mean sea level changes in the recent past. In: Warrick R. A., Barrow E. M. \& Wigley T. M. L. eds. Climate and Sea Level Change: Observations, Projections and Implications, pp. 25-44. Cambridge University Press, Cambridge.

Hardy T., McConochie J. \& Mason L. 2003. Modelling tropical cyclone wave population of the Great Barrier Reef. Journal of Waterway, Port, Coastal and Ocean Engineering 129, 104-113.

Hopley D. 1982. Geomorphology of the Great Barrier Reef: Quaternary Development of Coral Reefs. Wiley, New York.

Jell J. S. \& Flood P. G. 1978. Guide to the geology of reefs of the Capricorn and Bunker Groups, Great Barrier Reef Province, with special reference to Heron Reef. University of Queensland Department of Geology Papers 8, 1-85.

Jell J. S., Maxwell W. G. H. \& McKellar R. G. 1965. The significance of the larger Foraminifera in the Heron Island reef sediments. Journal of Paleontology 39, 273-279.

Johnson D. P., Belperio A. P. \& Hopley D. 1986. A field guide to mixed terrigenous-clastic sedimentation in the central Great Barrier Reef Province, Australia. Geological Society of Australia, Australian Sedimentologists Group, Field Guide Series 3 .

Johnson D. P. \& Carter R. M. 1987. Sedimentary framework of mainland fringing reef development, Cape Tribulation area. Great Barrier Reef Marine Park Authority Technical Memorandum 14.

Johnson D. P., Cuff C. \& Rhodes E. 1984. Holocene reef sequences and geochemistry, Britomart Reef, central Great Barrier Reef, Australia. Sedimentology 31, 515-529.

Kershaw A. P. 1978. Record of last interglacial-cycle from northeast Queensland. Nature 272, 159-161.

Kidwell S. M., Best M. M. R. \& Kaufman D. S. 2005. Taphonomic tradeoffs in tropical marine death assemblages: differential time-averaging, shell loss, and probable bias in siliciclastic vs carbonate facies. Geology 33, 729-732.

Kowalewski M. \& Bambach R. K. 2003. The limits of paleontological resolution. In: Harries P. J. ed. High Resolution Approaches in Stratigraphic Paleontology (Topics in Geobiology Series 21), pp. 1-48. Plenum Press, New York.

Larcombe P. \& Carter R. M. 2004. Cyclone pumping, sediment partitioning and the development of the Great Barrier Reef shelf system: a review. Quaternary Science Reviews 23, 107-135.

Larcombe P., Carter R. M., Dye J., Gagan M. K. \& Johnson D. P. 1995. New evidence for episodic post-glacial sea-level rise, central Great Barrier Reef, Australia. Marine Geology 127, 1-44.

Larcombe P. \& Woolfe K. J. 1999. Note: Increased sediment supply to the Great Barrier Reef will not increase sediment accumulation at most coral reefs. Coral Reefs 18, 163-169.

Magee J. W., Miller G. H., Spooner N. A. \& Questiaux D. 2004. Continuous 150 k.y. monsoon record from Lake Eyre, Australia: insolation-forcing implications and unexpected Holocene failure. Geology 32, 885-888.
Marshall J. F. \& Davies P. J. 1982. Internal structure and Holocene evolution of One Tree Reef, southern Great Barrier Reef. Coral Reefs 1, 21-28.

Maxwell W. G. H. 1968. Atlas of the Great Barrier Reef. Elsevier, Amsterdam.

Mclean R. F. \& Stoddart D. R. 1978. Reef island sediments of the northern Great Barrier Reef. Philosophical Transactions of the Royal Society of London A291, 101-117.

Mclean R. F., Stoddart D. R., Hopley D. \& Polach H. 1978. Sea level change in the Holocene on the northern Great Barrier Reef. Philosophical Transactions of the Royal Society of London A291, 167-186.

Miller G. H., Mangan J., Pollard D., Thompson S., Felzer B. \& Magee J. 2005. Sensitivity of the Australian Monsoon to insolation and vegetation: implications for human impact on continental moisture balance. Geology 33, 65-68.

Mitchell W. 1999. Australian mean sea level survey. Permanent Committee on Tides and Mean Sea Level Circular 43.

Moorhouse F. W. 1936. The cyclone of 1934 and its effects on Low Isles, with special observations on Porites. Reports of the Great Barrier Reef Committee 4, 37-44.

Nott J. \& Price D. 1994. Plunge pools and paleoprecipitation. Geology 22, 1047-1050.

Orme G. R., Flood P. G. \& Sargent G. E. G. 1978a. Sedimentation trends in the lee of outer (ribbon) reefs, Northern Region of the Great Barrier Reef Province. Philosophical Transactions of the Royal Society of London A291, 85-99.

Orme G. R., Webb J. P., Kelland N. C. \& Sargent G. E. G. 1978b. Aspects of the geological history and structure of the northern Great Barrier Reef. Philosophical Transactions of the Royal Society of London A291, 23-35.

Orpin A. R., Ridd P. V. \& Stewart L. K. 1999. Assessment of the relative importance of major sediment-transport mechanisms in the central Great Barrier Reef lagoon. Australian Journal of Earth Sciences 46, 883-896.

Polach H. A., Mclean R. F., Caldwell F. R. \& Thom B. G. 1978. Radiocarbon ages from the northern Great Barrier Reef. Philosophical Transactions of the Royal Society of London A291, 139-158.

Schlager W. 1981. The paradox of drowned reefs and carbonate platforms. Geological Society of America Bulletin 91, 197-211.

Searle D. E., Harvey N. \& Hopley D. 1980. Preliminary results of continuous seismic profiling on the Great Barrier Reef province between $16810_{0} S$ and $19820_{0}$ S. Geological Survey of Queensland Record 23.

Shulmeister J. 1992. A Holocene pollen record from lowland tropical Australia. The Holocene 2, 107-116.

Smith B. T., Frankel E. \& Jell J. S. 1998. Lagoonal sedimentation and reef development on Heron Reef, southern Great Barrier Reef Province. In: Camoin G. F. \& Davies P. J. eds. Reefs and Carbonate Platforms in the Pacific and Indian Oceans, pp. 281- 294. International Association of Sedimentologists Special Publication 25, 281-294.

Spender M. A. 1930. Island reefs of the Queensland coast. Geographical Journal 76, 194-214, 273-297.

Wyrwoll K-H. \& Miller G. H. 2001. Initiation of the Australian summer monsoon 14,000 years ago. Quaternary International 83/85, 119-128. 